\title{
О ТЕРМИЧЕСКОЙ УСТОИЧИВОСТИ ПОЛИКАПРОАМИДА, МОДИФИЦИРОВАННОГО НЕФТЯНЫМИ ПЕКАМИ
}

T. DZASIASVILI, J. KRJAZEV, O. KIRRET, Aili KOGERMAN. NAFTAPIGIDEGA MODIFITSEERITUD POLUKAPROAMIIDKIUDUDE TERMILINE STABIILSUS

T. DZHASHIASHVILI, J. KRYAZHEV, O. KIRRET, Aili KOGERMAN. THERMAL STABILITY OF PETROLEUM PITCH MODIFIED POLYCAPROAMIDE FIBRES

Асфальто-смолистые вещества нефти являются высокоэффективными ингибиторами термической и термоокислительной деструкции полимеров [']. В сущности нефтяные пеки представляют собой концентрат смолисто-асфальтенового характера [ $\left.{ }^{2}\right]$.

В литературе имеются отдельные сведения о возможности модификации свойств волокнообразующих полимеров с помощью битумов и пеков. Формованием волокна из смесей расплавов битумов и пеков с полиолефинами получаются при этом достаточно прочные и пригодные для эксплуатации волокна. Однако систематических исследований в области модификации волокон с использованием нефтяных пеков не проводилось. В частности, до сих пор не исследована термическая устойчивость волокон при введении малых добавок нефтяных пеков. В то же время имеются указания на проявление нефтяными асфальтенами ингибирующей способности в процессах термоокислительной деструкции поликапроамида (ПКА) ['].

В данной работе исследована возможность повышения термической устойчивости ПКА-волокон путем введения в них небольших количеств нефтяных пеков (до 10\% от массы волокна).

Для получения волокон использовали три образца пеков, приготовленных из асфальта кубового остатка западносибирской нефти. Эти образцы получали путем длительного нагревания асфальта в инертной атмосфере с постепенным повышением температуры. Выяснилось, что с увеличением конечной температуры обработки пека возрастают температура его плавления и содержание нерастворимой в толуоле фракцин, а индекс течения падает (табл. 1). Эти изменения связаны с протекающими в ходе термообработки конденсационными процессами и отгонкой низкомолекулярных фракций, что приводит к возрастанию средней молекулярной массы компонентов пека и их структурированию.

Отсутствие в пеках № 1 и 3 фракции, растворимой в хинолине, и ее низкое содержание в пеке № 2 свидетельствуют, что выбранный режим подготовки пеков является достаточно мягким и что в них практически нет неплавких карбоидных частиц. Была установлена также растворимость использованных пеков в капролактаме.

Для введения пековых добавок в ПКА нами было исследовано два способа: 1) полиамидирование капролактама в присутствии пека; 2) смешение пеков с ПКА в экструдере. 
Условия получения и характеристика пеков

\begin{tabular}{|c|c|c|c|c|c|c|}
\hline \multirow{2}{*}{$\begin{array}{l}\text { Номер } \\
\text { пека }\end{array}$} & \multirow{2}{*}{$\begin{array}{l}\text { Темпера- } \\
\text { тура об- } \\
\text { работки, } \\
{ }^{\circ} \mathrm{C}\end{array}$} & \multirow{2}{*}{$\begin{array}{l}\text { Время } \\
\text { обра- } \\
\text { ботки, } \\
\text { ч }\end{array}$} & \multirow{2}{*}{$\begin{array}{c}\text { Tемпера- } \\
\text { тура } \\
\text { плавле- } \\
\text { ния, } \\
{ }^{\circ} \mathrm{C}\end{array}$} & \multirow{2}{*}{$\begin{array}{l}\text { Индекс } \\
\text { течения } \\
\text { при } \\
235^{\circ} \mathrm{C}\end{array}$} & \multicolumn{2}{|c|}{$\begin{array}{c}\text { Содержание нераст- } \\
\text { воримых фракций, } \\
\%\end{array}$} \\
\hline & & & & & $\begin{array}{l}\text { в толуоле } \\
\text { ( } \beta \text {-фрак- } \\
\text { ция) }\end{array}$ & $\begin{array}{l}\text { в хино- } \\
\text { лине } \\
\text { ( } \gamma \text {-фрак- } \\
\text { ция) }\end{array}$ \\
\hline 1 & $\begin{array}{l}250 \\
290 \\
330 \\
380\end{array}$ & $\begin{array}{l}7 \\
7 \\
7 \\
7,5\end{array}$ & 225 & 0,8 & 38,9 & - \\
\hline 2 & $\begin{array}{l}252 \\
290 \\
331 \\
360\end{array}$ & $\begin{array}{l}7 \\
7 \\
7 \\
5\end{array}$ & 200 & 0,9 & 3,1 & 0,27 \\
\hline 3 & $\begin{array}{l}240 \\
290 \\
330\end{array}$ & $\begin{array}{c}7 \\
7 \\
10,5\end{array}$ & 190 & 62 & 0,2 & - \\
\hline
\end{tabular}

таблица 2

Физико-механические показатели поликапроамидных волокон, содержащих пеки

\begin{tabular}{c|c|c|c|c}
\hline Образец & $\begin{array}{c}\text { Содержание } \\
\text { пека, \% }\end{array}$ & $\begin{array}{c}\text { Относит. } \\
\text { вязкость }\end{array}$ & $\begin{array}{c}\text { Прочность, } \\
\text { сН/текс }\end{array}$ & $\begin{array}{c}\text { Удлинение, } \\
\%\end{array}$ \\
\hline
\end{tabular}

Способ полиамидирования

Поликапроамид

Он же с пеком № 3

$\begin{array}{rr}\overline{0}, 3 & 2,72 \\ 0,5 & 2,35 \\ 1,0 & 2,33 \\ 5,0 & 2,40 \\ 10,0 & 2,35 \\ & 2,14\end{array}$

Способ смешения в экструдере

Поликапроамид

Он же с пеком № 3

, с пеком № 2

" с пеком № 1

$\begin{array}{rr}- & 2,76 \\ 1,0 & 2,60 \\ 3,0 & 2,52 \\ 5,0 & 2,45 \\ 10,0 & 2,40 \\ 0,1 & 2,50 \\ 0,1 & 2,45 \\ 0,3 & 2,42\end{array}$

$\begin{array}{ll}67,46 & 23,00 \\ 32,62 & 41,05 \\ 35,27 & 37,95 \\ 31,70 & 43,35 \\ 25,70 & 58,10 \\ 26,95 & 50,65\end{array}$

$\begin{array}{ll}63,66 & 27,80 \\ 66,17 & 21,50 \\ 52,69 & 35,80 \\ 50,99 & 35,00 \\ 53,52 & 28,00 \\ 45,42 & 25,90 \\ 49,80 & 34,50 \\ 55,10 & 19,50\end{array}$

Волокна, полученные вторым способом, имеют более высокие физико-механические показатели по сравнению с волокнами, сформованными из модифицированного полиамидированием полимера (табл. 2). Следовательно, для введения пеков в термопластичный полимер целесообразно использовать способ смешения этих композиций в экструдере.

Для определения термической устойчивости ПКА, содержащего малые добавки нефтяных пеков, был проведен термогравиметрический и дифференциально-термический анализы (ДТА) полученных волокон при динамическом нагревании на воздухе в температурном интервале $20-1000^{\circ} \mathrm{C}$ и скорости нагревания $10^{\circ} /$ мин (на дериватографе системы «Paulik-Paulik-Erdei»). 


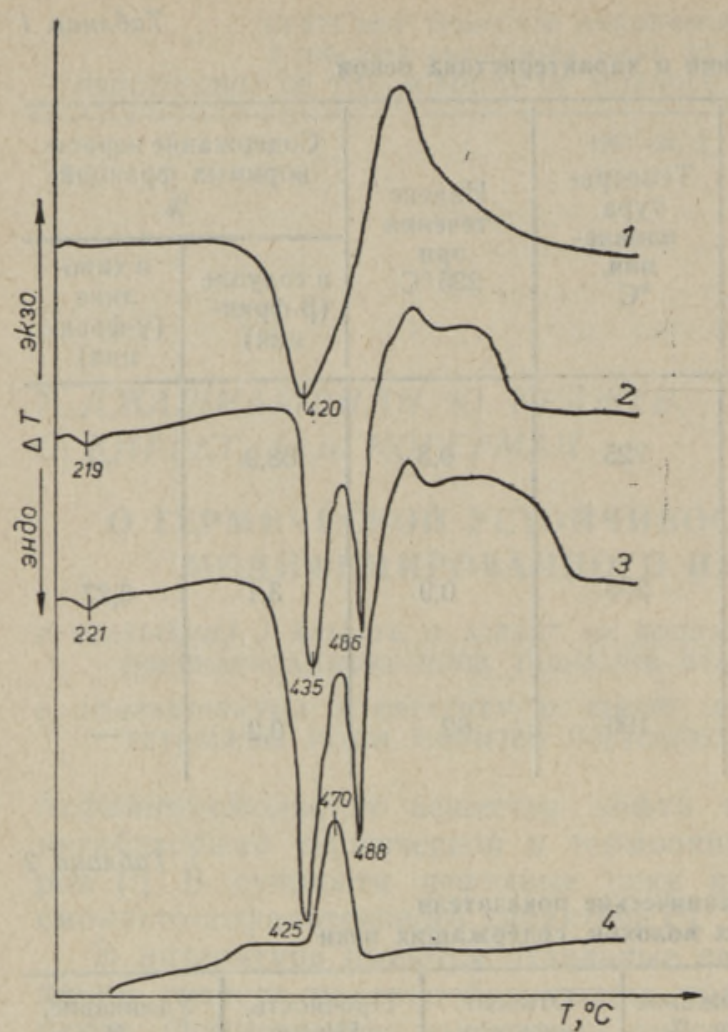

Рис. 1. Термограммы композиций поликапроамнд-пек: исходный ПКА (1), ПКА с $5 \%$ пека № 3 (2), ПКА с $10 \%$ пека № 3 (3), пек № 3 (4).

Анализ летучих продуктов пиролиза ПКА-волокон проводили в системе ступенчатой пиролизной газовой хроматографии (СПГХ) [3]. Образец волокна ( 0,3 мг), взвешенный в кварцевую трубку, нагревали в микрореакторе в пределах температур $200-500^{\circ}$. Температуру в реакторе ступенчато поднимали через $20^{\circ}$. После каждого нагрева (15 c) определяли в продуктах пиролиза в-капролактам, $\mathrm{CO}, \mathrm{CO}_{2}, \mathrm{NH}_{3}$ и $\mathrm{H}_{2} \mathrm{O}\left[{ }^{4}\right]$.

Исследования показали, что с введением пеков в ПКА существенно (на $50-70^{\circ}$ ) повышается температура начала интенсивного термораспада композиции (рис. 1), тогда как поведение кривой потери массы ПКА, для которого типична деполимеризация в узком температурном интервале с наложением термоокислительных процессов на заключительном этапе распада, не меняется. Большие изменения наблюдаются на кривых ДТА. Если деполимеризация ПКА характеризуется эндотермическим пиком в области $420^{\circ}$, а термоокислительные процессы характеризуются экзотермой с максимумом при $530^{\circ}$, то для волокон, содержащих пеки, наблюдаются расщепление эндотермического пика на два острых минимума при 430 и $480^{\circ}$, а также появление высокотемпературного плеча в экзотермической части кривой $\left(550-630^{\circ}\right)$. Указанные изменения на кривых ДТА не являются результатом наложения процессов термоокислительного распада непосредственно пека, для которого прослеживается медленная потеря массы выше $350-400^{\circ}$, причем даже при $1000^{\circ}$ полного выгорания образца не происходит коксовый остаток составляет $40 \%$. На кривой ДТА для пека наблюдается только малоинтенсивный пик при $470^{\circ}$. Следует также отметить, что с повышением добавки пека в ПКА от 6 до 10\% заметных изменений на кривых ДТА модифицированных волокон не наблюдается. Таким образом, можно полагать, что добавка пеков существенно изменяет характер термоокислительных процессов, протекающих при нагре- 
Рис. 2. Скорость выделения $\varepsilon$-капролактама при пиролизе пековых волокон: исходный ПКА (1), ПКА с $1 \%$ пека № 3 (2), ПКА с $2 \%$ пека № 3 (3).

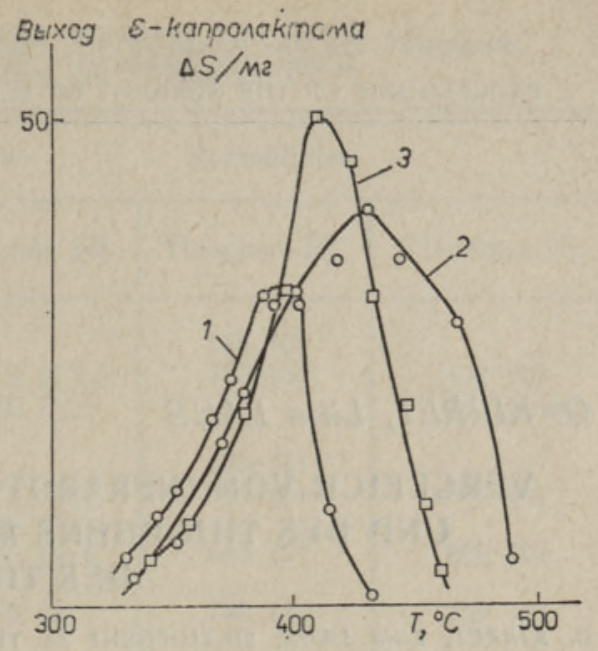

вании ПКА, и ингибирует эти процессы выше $300^{\circ}$, увеличивая температуру начала распада ПКА. Кривые скорости выделения $\varepsilon$-капролактама при СПГХ пековых волокон указывают на изменение механизма термораспада ПКА в присутствии пеков: имеет место снижение общего количества $\varepsilon$-капролактама при пиролизе ПКА с малым количеством пековых добавок (рис. 2).

\section{Выводы}

1. Исследованы два способа введения малых добавок нефтяных пеков в поликапроамид (полиамидирование капролактама в присутствии пеков и смешение композиций пек-поликапроамид в экструдере) и свойства получаемых волокон.

2. Показано, что поликапроамид с добавками пеков проявляет устойчивость к термоокислительной деструкции при температурах выше $300^{\circ} \mathrm{C}$.

\section{Л ИТ Е Р А Т У А}

1. Сидоренко А. А., Боголюбов В. М., Кряжев Ю. Г. Исследование ингибирующей способности высокомолекулярных компонентов сернистых нефтей. - В кн.: IX Международный симпозиум по химии органических соединеннй среды. Тезисы докл. Рига, 1980, 329.

2. Калонтаров Н. Я., Елисеев В. С., Кряжев Ю. Г. Светостабилизация ацетилцеллюлозы. - Пластмассы, 1977, № 12, 58-63.

3. Heinsoo, E., Kogerman, A., Kirret, O., Coupek, J., Vilkova, S. Stepwise pyrolysisgas chromatography of viscose fibres. - J. Anal. Appl. Pyrol., 1980, 2, N 2, $131-139$.

4. Heinsoo, E., Kogerman, A. Stepwise pyrolysis-gas chromatography of nylon-6. In: Proceedings of the 3rd Danube Symposium on Chromatography, Aug. 31 Sept. 4, 1981. Siófok, Hungary, 143-146.

Московский текстильный институт

Ннститут химии

Академии наук Эстонской ССР
Поступила в редакцию 10/XII 1984 